Article

\title{
Five New Biphenanthrenes from Cremastra appendiculata
}

\author{
Liang Liu ${ }^{1,2,3}$, Jun Li ${ }^{4}$, Ke-Wu Zeng ${ }^{1}$, Yong Jiang ${ }^{1}$ and Peng-Fei Tu ${ }^{1, *}$ \\ 1 State Key Laboratory of Natural and Biomimetic Drugs, School of Pharmaceutical Sciences, \\ Peking University Health Science Center, Beijing 100191, China; enjoyyz@163.com (L.L.); \\ ZKW@bjmu.edu.cn (K.-W.Z.); yongjiang@bjmu.edu.cn (Y.J.) \\ 2 Medical College, Yangzhou University, Yangzhou 225009, China \\ 3 Jiangsu Key Laboratory of Zoonosis, Jiangsu Co-innovation Center for Prevention and Control of Important \\ Animal Infectious Diseases and Zoonoses, Yangzhou University, Yangzhou 225009, China \\ 4 Modern Research Center for Traditional Chinese Medicine, Beijing University of Chinese Medicine, \\ Beijing 100029, China; drlj666@163.com \\ * Correspondence: pengfeitu@vip.163.com; Tel.: +86-10-8280-2750 \\ Academic Editor: Dong-Kug Choi \\ Received: 3 July 2016; Accepted: 15 August 2016; Published: 19 August 2016
}

\begin{abstract}
Five new biphenanthrenes, cremaphenanthrenes A-E (1-5), along with six known ones, were isolated from the ethanolic extract of the tubers of Cremastra appendiculata (D. Don) Makino (Orchidaceae). Their structures were elucidated on the basis of extensive spectroscopic analyses. All the compounds obtained were tested in vitro for cytotoxic activities against colon (HCT-116), cervix (Hela), and breast (MDA-MB-231) cancer cell lines. They all showed moderate or weak cytotoxicities to the above cancer cell lines.
\end{abstract}

Keywords: Cremastra appendiculata; biphenanthrene; cytotoxic activity

\section{Introduction}

Phenanthrenes are a rather uncommon class of aromatic metabolites, which are presumably formed by oxidative coupling of the aromatic rings of stilbene precursors, and have been reported in higher plants, mainly in the Orchidaceae family [1]. The phenanthrenes isolated thus far may be classified into three major groups: monophenanthrenes, biphenanthrenes, and triphenanthrenes, and most natural phenanthrenes occur in monomeric form [1]. To date, less than one hundred biphenanthrenes and two triphenanthrenes have been isolated from the Orchidaceae family [2-13]. Biphenanthrenes have been reported to possess various biological activities including cytotoxicity, antimicrobial, spasmolytic, anti-inflammatory, antiplatelet aggregation, and antiallergic activities [1]. Currently, the cytotoxic activities of biphenanthrenes have attracted much interest, and biphenanthrenes may potentially be served as novel class of antitumor candidate [4].

The tuber of Cremastra appendiculata (D. Don) Makino (Orchidaceae) is one main source of "Shancigu", which is a famous traditional Chinese medicine with a long history for treating cancers [14]. About forty phenanthrenes, including ten biphenanthrenes, have been isolated from this title plant in previous phytochemical investigations $[2,3,13,15,16]$. The in vitro cytotoxic activities of some biphenanthrenes are better than the corresponding monomeric phenanthrenes [1,2]. In a previous article, eight new benzylphenanthrenes, and a few known compounds, were reported from this herb $[13,15,16]$. Our continuing investigations on the constituents of this plant have led to the isolation of five new biphenanthrenes, together with six known ones (Figure 1). In this paper, we report the structural identification of five previously unreported biphenanthrenes, namely cremaphenanthrenes A-E (1-5), as well as their cytotoxic activities. 

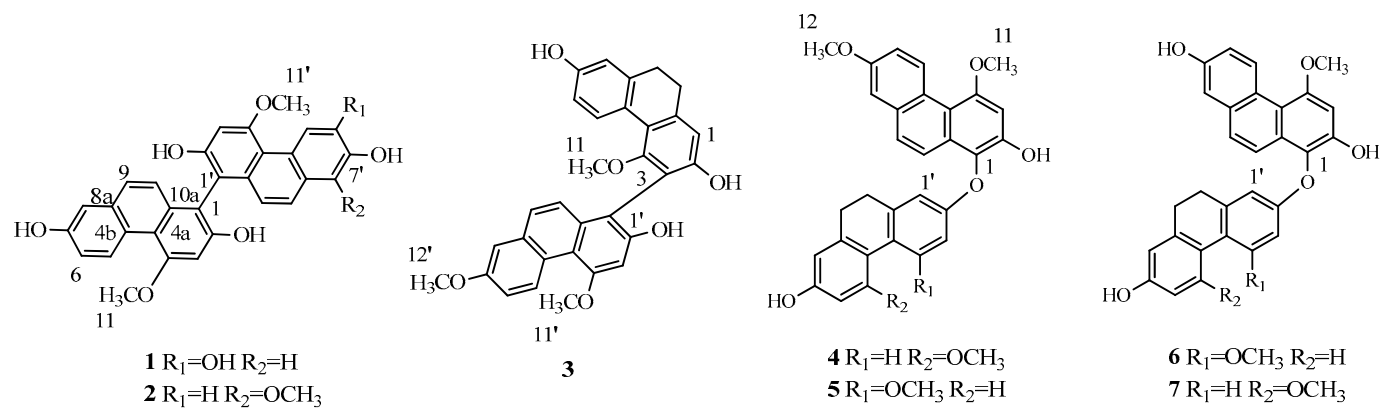

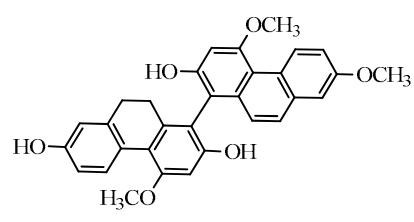

8

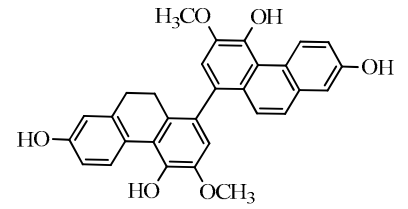

9

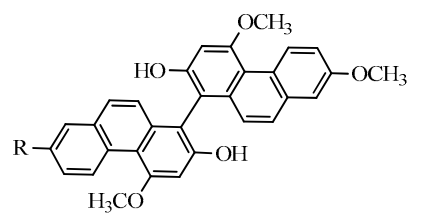

$10 \mathrm{R}=\mathrm{OH}$

$11 \mathrm{R}=\mathrm{OCH}_{3}$

Figure 1. Structures of compounds 1-11 isolated from C. appendiculata.

\section{Results and Discussion}

The tubers of $C$. appendiculata were extracted with $95 \% \mathrm{EtOH}$ to yield a dark brown residue, which was suspended in distilled water and partitioned successively with petroleum ether (PE), ethyl acetate (EtOAc), and $n$-butyl alcohol $(n-\mathrm{BuOH})$. The PE and EtOAc partitions were chromatographed over silica gel, Sephadex LH-20 and ODS columns, and semi-preparative HPLC to obtain eleven biphenanthrenes (1-11) (Figure 1). Their structures were elucidated based on extensive spectroscopic analyses (Supplementary Materials).

\subsection{Structure Elucidation}

Compound 1 (Tables 1 and 2, Figure 2) was obtained as a brown amorphous powder. The positive ion HR-ESI-MS showed an ion at $m / z 1011.2639[2 \mathrm{M}+\mathrm{Na}]^{+}$and established the molecular formula as $\mathrm{C}_{30} \mathrm{H}_{22} \mathrm{O}_{7}$. The IR spectrum showed absorption bands at $3239,1612,1588$, and $1206 \mathrm{~cm}^{-1}$ ascribable to hydroxyl and aromatic functions, respectively. The UV spectrum showed absorption maximum at 203, 264, and $308 \mathrm{~nm}$. The ${ }^{1} \mathrm{H}-\mathrm{NMR}$ spectrum displayed eleven aromatic protons signals including one set of ABX coupling systems at $\delta_{\mathrm{H}} 9.36(1 \mathrm{H}, \mathrm{d}, J=9.0 \mathrm{~Hz}, \mathrm{H}-5), 7.09(1 \mathrm{H}, \mathrm{dd}, J=9.0,3.0 \mathrm{~Hz}$, $\mathrm{H}-6)$ and $7.04(1 \mathrm{H}, \mathrm{d}, J=3.0 \mathrm{~Hz}, \mathrm{H}-8)$; four singlets signals at $\delta_{\mathrm{H}} 6.97(1 \mathrm{H}, \mathrm{s}, \mathrm{H}-3), 6.92\left(1 \mathrm{H}, \mathrm{s}, \mathrm{H}-3^{\prime}\right)$, $8.96\left(1 \mathrm{H}, \mathrm{s}, \mathrm{H}-5^{\prime}\right)$ and $7.02\left(1 \mathrm{H}, \mathrm{s}, \mathrm{H}-8^{\prime}\right)$; two pairs of doublets signals at $\delta_{\mathrm{H}} 7.28(1 \mathrm{H}, \mathrm{d}, J=9.0 \mathrm{~Hz}$, $\mathrm{H}-9), 6.90(1 \mathrm{H}, \mathrm{d}, J=9.0 \mathrm{~Hz}, \mathrm{H}-10), 7.20\left(1 \mathrm{H}, \mathrm{d}, J=9.0 \mathrm{~Hz}, \mathrm{H}-9^{\prime}\right)$, and $6.71\left(1 \mathrm{H}, \mathrm{d}, J=9.0 \mathrm{~Hz}, \mathrm{H}-10^{\prime}\right)$. In addition, two methoxy singlets signals at $\delta_{\mathrm{H}} 4.10\left(6 \mathrm{H}, \mathrm{s}, \mathrm{H}-11, \mathrm{H}-11^{\prime}\right)$ were observed as well. The ${ }^{13} \mathrm{C}-\mathrm{NMR}$ spectrum of $\mathbf{1}$ displayed twenty eight aromatic carbons (including seven oxygenated quaternary aromatic ones, whose chemical shifts were above $140 \mathrm{ppm}$ ) and two methoxy carbons signals. These data, especially the presence of the deshielded protons signals at $\delta_{\mathrm{H}} 9.36(\mathrm{H}-5)$ and $8.96\left(\mathrm{H}-5^{\prime}\right)$ indicated compound 1 was an asymmetrical biphenanthrene with five hydroxyls and two methoxyls as substituents. The substituent positions of 1 were further confirmed by 2D-NMR experiments. Based on the HMBC correlations from H-3 to C-1, C-2, C-4 and C-4a, H-5 to C-4a, C-6, C-7 and C-8a, H-6 to C-4b and C-8, H-8 to C-4b, C-6, C-7 and C-9, H-9 to C-4b, C-8, C-8a and C-10a, $\mathrm{H}-10$ to $\mathrm{C}-1, \mathrm{C}-4 \mathrm{a}$ and C-8a, H-11 to C-4, and NOESY correlations from $\delta_{\mathrm{H}} 4.10(\mathrm{H}-11)$ to $6.97 \mathrm{~s}(\mathrm{H}-3)$ and $9.36(\mathrm{H}-5)$, one phenanthrene unit was determined to be 2,7-hydroxy-4-methoxyphenanthrene. HMBC correlations from $\mathrm{H}-3^{\prime}$ to $\mathrm{C}-1^{\prime}, \mathrm{C}-2^{\prime}, \mathrm{C}-4^{\prime}$ and $\mathrm{C}-4 \mathrm{a}^{\prime}, \mathrm{H}-5^{\prime}$ to $\mathrm{C}-4 \mathrm{a}^{\prime}, \mathrm{C}-\mathrm{7}^{\prime}$ and $\mathrm{C}-8 \mathrm{a}^{\prime}, \mathrm{H}-8^{\prime}$ to $\mathrm{C}-4 \mathrm{~b}^{\prime}$, $\mathrm{C}-6^{\prime}, \mathrm{C}-7^{\prime}$ and C-9' ${ }^{\prime}, \mathrm{H}-9^{\prime}$ to $\mathrm{C}-4 \mathrm{~b}^{\prime}, \mathrm{C}-8^{\prime}, \mathrm{C}-8 \mathrm{a}^{\prime}$ and $\mathrm{C}-10 \mathrm{a}^{\prime}, \mathrm{H}-10^{\prime}$ to $\mathrm{C}-1^{\prime}, \mathrm{C}-4 \mathrm{a}^{\prime}$ and $\mathrm{C}-8 \mathrm{a}^{\prime}, \mathrm{H}-11^{\prime}$ to 
C-4', and NOESY correlations from $\delta_{\mathrm{H}} 4.10\left(\mathrm{H}-11^{\prime}\right)$ to $6.92\left(\mathrm{H}-3^{\prime}\right)$ and $8.96\left(\mathrm{H}-5^{\prime}\right)$ revealed the other phenanthrene unit was $2^{\prime}, 6^{\prime}, 7^{\prime}$-trihydroxy-4'-methoxyphenanthrene. According to the HSQC and HMBC spectra, $\delta_{C} 111.3(\mathrm{C}-1)$ and $\delta_{C} 110.6\left(\mathrm{C}-1^{\prime}\right)$ were two quaternary aromatic carbons, suggesting the two phenanthrene units to be connected directly by $\mathrm{C}-1$ and $\mathrm{C}-1^{\prime}$. Therefore, the structure of 1 was established as $2,7,2^{\prime}, 6^{\prime}, 7^{\prime}$-pentahydroxy-4,4'-dimethoxy-1,1'-biphenanthrene, and named as cremaphenanthrene A.
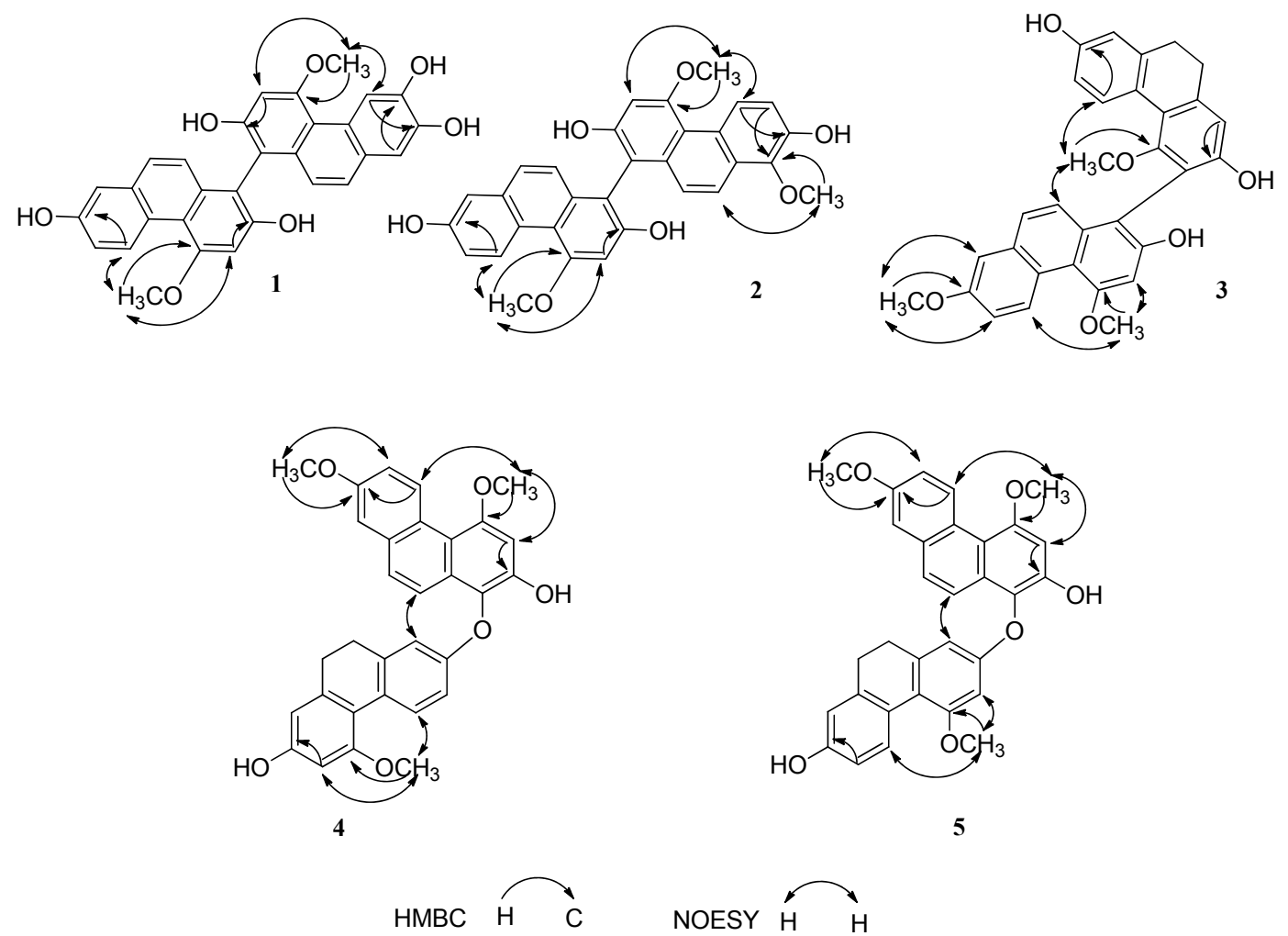

Figure 2. Key NOESY and HMBC correlations of compounds 1-5.

Table 1. ${ }^{1} \mathrm{H}-\mathrm{NMR}$ Data of compounds $1-3$.

\begin{tabular}{cccc}
\hline Proton & $\mathbf{1}^{\mathbf{a}}$ & $\mathbf{2}^{\mathbf{b}}$ & $\mathbf{3}^{\mathbf{b}}$ \\
\hline 1 & & & $6.71 \mathrm{~s}$ \\
3 & $6.97 \mathrm{~s}$ & $7.00 \mathrm{~s}$ & \\
5 & $9.36 \mathrm{~d}(9.0)$ & $9.38 \mathrm{~d}(9.0)$ & $8.08 \mathrm{~d}(9.0)$ \\
6 & $7.09 \mathrm{dd}(9.0,3.0)$ & $7.10 \mathrm{dd}(9.0,3.0)$ & $6.63 \mathrm{dd}(9.0,3.0)$ \\
8 & $7.04 \mathrm{~d}(3.0)$ & $7.06 \mathrm{~d}(3.0)$ & $6.69 \mathrm{~d}(3.0)$ \\
9 & $7.28 \mathrm{~d}(9.0)$ & $7.31 \mathrm{~d}(9.0)$ & $2.73-2.78 \mathrm{~m}^{\mathrm{c}}$ \\
10 & $6.90 \mathrm{~d}(9.0)$ & $6.91 \mathrm{~d}(9.0)$ & $2.73-2.78 \mathrm{~m}^{\mathrm{c}}$ \\
$3^{\prime}$ & $6.92 \mathrm{~s}$ & $7.00 \mathrm{~s}$ & $6.96 \mathrm{~s}$ \\
$5^{\prime}$ & $8.96 \mathrm{~s}$ & $9.17 \mathrm{~d}(9.0)$ & $9.50 \mathrm{~d}(9.0)$ \\
$6^{\prime}$ & & $7.20 \mathrm{~d}(9.0)$ & $7.17 \mathrm{dd}(9.03 .0)$ \\
$8^{\prime}$ & $7.02 \mathrm{~s}$ & & $7.25 \mathrm{~d}(3.0)$ \\
$9^{\prime}$ & $7.20 \mathrm{~d}(9.0)$ & $7.66 \mathrm{~d}(9.0)$ & $7.53 \mathrm{~d}(9.0)$ \\
$10^{\prime}$ & $6.71 \mathrm{~d}(9.0)$ & $6.98 \mathrm{~d}(9.0)$ & $7.36 \mathrm{~d}(9.0)$ \\
$4-\mathrm{OCH}_{3}$ & $4.10 \mathrm{~s}$ & $4.12 \mathrm{~s}$ & $3.14 \mathrm{~s}$ \\
$4^{\prime}-\mathrm{OCH}_{3}$ & $4.10 \mathrm{~s}$ & $4.14 \mathrm{~s}$ & $4.15 \mathrm{~s}$ \\
$7^{\prime}-\mathrm{OCH}_{3}$ & & & $3.92 \mathrm{~s}$ \\
$8^{\prime}-\mathrm{OCH}_{3}$ & & $3.76 \mathrm{~s}$ & \\
\hline
\end{tabular}

a ${ }^{1} \mathrm{H}-\mathrm{NMR}$ data were measured at $600 \mathrm{MHZ}$ in DMSO- $d_{6}$ for $1, \delta$ in ppm, $J$ in $\mathrm{Hz} ;{ }^{\text {b }}{ }^{1} \mathrm{H}-\mathrm{NMR}$ data were measured at $500 \mathrm{MHZ}$ in DMSO- $d_{6}$ for 2 , in $\mathrm{CD}_{3} \mathrm{OD}$ for $3, \delta$ in ppm, $J$ in $\mathrm{Hz}$; ${ }^{\mathrm{c}}$ overlapped; the number in brackets represented coupling constants. 
Table 2. ${ }^{13}$ C-NMR Data of compounds $\mathbf{1}-\mathbf{3}$.

\begin{tabular}{|c|c|c|c|}
\hline Carbon & $1^{a}$ & $2^{b}$ & $3^{b}$ \\
\hline 1 & 111.3 & 111.0 & 112.3 \\
\hline 2 & 153.3 & 153.5 & 156.0 \\
\hline 3 & 99.7 & $99.7^{c}$ & 117.7 \\
\hline 4 & 157.9 & 157.9 & 158.6 \\
\hline 5 & 128.8 & 128.8 & 129.6 \\
\hline 6 & 116.6 & 116.6 & 114.4 \\
\hline 7 & 154.1 & 154.1 & 156.8 \\
\hline 8 & 110.9 & 110.9 & 115.4 \\
\hline 9 & 126.7 & 126.8 & 31.8 \\
\hline 10 & 125.0 & 124.7 & 31.4 \\
\hline $4 a$ & 114.2 & 114.2 & 121.1 \\
\hline $4 b$ & 123.6 & 123.6 & 126.3 \\
\hline $8 a$ & 132.5 & 132.4 & 140.9 \\
\hline $10 a$ & 133.4 & 133.3 & 141.9 \\
\hline $1^{\prime}$ & 110.6 & 111.0 & 110.9 \\
\hline $2^{\prime}$ & 153.1 & 153.3 & 154.3 \\
\hline $3^{\prime}$ & 99.0 & $99.8^{c}$ & 100.5 \\
\hline $4^{\prime}$ & 157.7 & 157.8 & 160.5 \\
\hline $5^{\prime}$ & 112.7 & 123.5 & 130.5 \\
\hline $6^{\prime}$ & 145.6 & 117.4 & 117.2 \\
\hline $7^{\prime}$ & 144.2 & 145.5 & 158.1 \\
\hline $8^{\prime}$ & 111.7 & 140.8 & 109.5 \\
\hline $9^{\prime}$ & 126.5 & 120.0 & 128.6 \\
\hline $10^{\prime}$ & 121.5 & 124.7 & 126.5 \\
\hline $4 a^{\prime}$ & 113.8 & 114.2 & 116.7 \\
\hline $4 b^{\prime}$ & 124.4 & 124.3 & 126.6 \\
\hline $8 a^{\prime}$ & 125.6 & 126.2 & 134.5 \\
\hline $10 a^{\prime}$ & 133.8 & 133.4 & 135.2 \\
\hline $4-\mathrm{OCH}_{3}$ & 55.5 & 55.5 & 60.0 \\
\hline $4^{\prime}-\mathrm{OCH}_{3}$ & 55.5 & 55.5 & 56.2 \\
\hline $7^{\prime}-\mathrm{OCH}_{3}$ & & & 55.8 \\
\hline $8^{\prime}-\mathrm{OCH}_{3}$ & & 60.3 & \\
\hline
\end{tabular}

a ${ }^{13} \mathrm{C}-\mathrm{NMR}$ data were measured at $150 \mathrm{MHZ}$ in DMSO- $d_{6}$ for $\mathbf{1}, \delta$ in $\mathrm{ppm} ;{ }^{\mathrm{b}}{ }^{13} \mathrm{C}-\mathrm{NMR}$ data were measured at $125 \mathrm{MHZ}$ in DMSO- $d_{6}$ for 2, in $\mathrm{CD}_{3} \mathrm{OD}$ for $3, \delta$ in ppm, $J$ in $\mathrm{Hz}^{\circ}{ }^{\mathrm{c}}$ the signals under the same superscript may be interchanged.

Compound 2 (Tables 1 and 2, Figure 2) was isolated as a brown amorphous powder. The molecular formula of 2 was determined as $\mathrm{C}_{31} \mathrm{H}_{24} \mathrm{O}_{7}$ from the negative ion HR-ESI-MS at $\mathrm{m} / z$ 507.1455 $[\mathrm{M}-\mathrm{H}]^{-}$. The IR and UV spectra were similar to those of 1 . The molecular weight of 2 was fourteen mass units more than that of $\mathbf{1}$. Moreover, two typical deshielded protons signals at $\delta_{\mathrm{H}}$ $9.38(\mathrm{H}-5)$ and $9.17\left(\mathrm{H}-5^{\prime}\right)$ in ${ }^{1} \mathrm{H}-\mathrm{NMR}$ spectrum, twenty eight aromatic carbons (including seven oxygenated quaternary aromatic ones), three methoxy carbons signals appeared in ${ }^{13} \mathrm{C}-\mathrm{NMR}$ spectrum, which suggested that 2 was also an asymmetrical biphenanthrene with four hydroxyls and three methoxyls as substituents. The substitution patterns of $\mathbf{2}$ were similar to those of $\mathbf{1}$ except for a methoxyl located at C-8 $8^{\prime}$ and the absence of a hydroxyl assigned to C- $6^{\prime}$, respectively. This was further confirmed by the HMBC correlations from $\mathrm{H}-8^{\prime}-\mathrm{OCH}_{3}$ to $\mathrm{C}-8^{\prime}, \mathrm{H}-6^{\prime}$ to $\mathrm{C}-8^{\prime}$, as well as the NOESY correlation from $\mathrm{H}-8^{\prime}-\mathrm{OCH}_{3}$ to $\mathrm{H}-9^{\prime}$. Thus, the structure of 2 was elucidated as 2,7, $2^{\prime}, 7^{\prime}$-tetrahydroxy-4,4', $8^{\prime}$-trimethoxy-1,1'-biphenanthrene, and named as cremaphenanthrene B.

Compound 3 (Tables 1 and 2, Figure 2) was obtained as a brown amorphous powder. A positive $[\mathrm{M}+\mathrm{H}]^{+}$ion at $m / z 495.1795$ was found in the HR-ESI-MS spectrum of 3, and given the molecular formula as $\mathrm{C}_{31} \mathrm{H}_{26} \mathrm{O}_{6}$. The $1 \mathrm{D}$ NMR spectra of 3 displayed two typical pairs of protons signals at $\delta_{\mathrm{H}}$ 2.73-2.78 $(4 \mathrm{H}, \mathrm{m}, \mathrm{H}-9,10)$, twenty six aromatic (including six oxygenated quaternary aromatic carbons), three methoxy carbons, and two methylenes signals, which suggested that compound 3 
was an asymmetrical phenanthrene-9,10-dihydrophenanthrene dimer with three hydroxyls and three methoxyls as substituents. The substitution patterns of 3 were determined by comprehensive analyses of HSQC, HMBC, and NOESY spectra, especially the correlations from H-11 $\left(\delta_{\mathrm{H}} 3.14\right)$ to $\mathrm{H}-5\left(\delta_{\mathrm{H}} 8.08\right)$; $\mathrm{H}-11^{\prime}\left(\delta_{\mathrm{H}} 4.15\right)$ to $\mathrm{H}-3^{\prime}\left(\delta_{\mathrm{H}} 6.96\right)$ and $\mathrm{H}-5^{\prime}\left(\delta_{\mathrm{H}} 9.50\right) ; \mathrm{H}-12^{\prime}\left(\delta_{\mathrm{H}} 3.92\right)$ to $\mathrm{H}-6^{\prime}\left(\delta_{\mathrm{H}} 7.17\right)$ and $\mathrm{H}-8^{\prime}\left(\delta_{\mathrm{H}} 7.25\right)$ in the NOESY spectrum. The linkage between the two moieties was deduced to be C-3 ( $\delta \mathrm{c} 117.7)$ and $C-1^{\prime}(\delta c 110.9)$ by quaternary aromatic carbon nature, chemical shifts, and the molecular composition, especially by the NOESY correlation from $\mathrm{H}-11\left(\delta_{\mathrm{H}} 3.14\right)$ to $\mathrm{H}-10^{\prime}\left(\delta_{\mathrm{H}} 7.36\right)$. Subsequently, the structure of 3 was determined as 2,7,2'-trihydroxy-4, $4^{\prime}, 7^{\prime}$-trimethoxy-9,10-dihydro-3,1'-biphenanthrene, and named as cremaphenanthrene $C$.

Compound 4 (Tables 3 and 4, Figure 2) was obtained as a brown amorphous powder. The molecular formula was assigned as $\mathrm{C}_{31} \mathrm{H}_{26} \mathrm{O}_{6}$ on the basis of a negative $[\mathrm{M}-\mathrm{H}]^{-}$ion at $m / z$ 493.1637 in HR-ESI-MS of 4. In the ${ }^{1} \mathrm{H}-\mathrm{NMR}$ spectrum, eleven aromatic protons signals, three methoxy singlet signals, and two typical pairs of protons signals at $\delta_{\mathrm{H}} 2.61-2.63\left(4 \mathrm{H}, \mathrm{m}, \mathrm{H}-9^{\prime}, \mathrm{H}-10^{\prime}\right)$ assigned to $9^{\prime}, 10^{\prime}$-dihydrophenanthrene were observed. In the ${ }^{13} \mathrm{C}$-NMR spectrum, twenty six aromatic and two methoxy carbons signals were displayed. These data indicated the presence of biphenanthrene, which was made up of a phenanthrene moiety and a $9^{\prime}, 10^{\prime}$-dihydrophenanthrene moiety. In the HMBC spectrum, correlations from H-3 to C-1, C-2, C-4 and C-4a, H-5 to C-4a, C-7 and C-8a, H-6 to C-4b, H-8 to C-4b, C-6 and C-9, H-9 to C-4b, C-8 and C-10a, H-10 to C-1 and C-4a, H-11 to C-4, and $\mathrm{H}-12$ to $\mathrm{C}-7$, together with the NOESY correlations from H-11 $\left(\delta_{\mathrm{H}} 4.12\right)$ to $\mathrm{H}-3\left(\delta_{\mathrm{H}} 6.94\right)$ and H-5 $\left(\delta_{\mathrm{H}}\right.$ 9.45), H-12 $\left(\delta_{\mathrm{H}} 3.91\right)$ to $\mathrm{H}-6\left(\delta_{\mathrm{H}} 7.20\right)$ and $\mathrm{H}-8\left(\delta_{\mathrm{H}} 7.26\right)$ were observed, which revealed the phenanthrene moiety to be 2-hydroxy-4,7-dimethoxyphenanthrene. The HMBC correlations from $\mathrm{H}-1^{\prime}$ to $\mathrm{C}-2^{\prime}$ and $\mathrm{C}-4 \mathrm{a}^{\prime}, \mathrm{H}-4^{\prime}$ to $\mathrm{C}-10 \mathrm{a}^{\prime}, \mathrm{C}-2^{\prime}$ and $\mathrm{C}-4 \mathrm{~b}^{\prime}, \mathrm{H}-6^{\prime}$ to $\mathrm{C}-4 \mathrm{~b}^{\prime}, \mathrm{C}-7^{\prime}$ and $\mathrm{C}-8^{\prime}, \mathrm{H}-9^{\prime}$ to $\mathrm{C}-4 \mathrm{~b}^{\prime}, \mathrm{C}-10 \mathrm{a}^{\prime}$ and $\mathrm{C}-8^{\prime}, \mathrm{H}-10^{\prime}$ to $\mathrm{C}-4 \mathrm{a}^{\prime}, \mathrm{C}-1^{\prime}$ and $\mathrm{C}-8 \mathrm{a}^{\prime}, \mathrm{H}-11^{\prime}$ to $\mathrm{C}-5^{\prime}$, along with the NOESY correlations from $\mathrm{H}-11^{\prime}\left(\delta_{\mathrm{H}} 3.80\right)$ to $\mathrm{H}-4^{\prime}\left(\delta_{\mathrm{H}} 8.05\right)$ and $\mathrm{H}-6^{\prime}\left(\delta_{\mathrm{H}} 6.38\right)$ were observed, which suggested the presence of $2^{\prime}, 7^{\prime}$-dihydroxy-5'-methoxy-9,10-dihydrophenanthrene. $C-1\left(\delta_{C} 130.9\right)$ of phenanthrene moiety was shifted downfield, and it was a quaternary aromatic carbon, so it might be linked with oxygen, which indicated the 9,10-dihydrophenanthrene moiety and the phenanthrene moiety were connected through C-1 and C-2' or C-1 and C- $7^{\prime}$. The NOESY correlation from $\mathrm{H}-10\left(\delta_{\mathrm{H}} 7.70\right)$ to $\mathrm{H}-1^{\prime}$ $\left(\delta_{\mathrm{H}} 6.67\right)$ confirmed the existence of $\mathrm{C}-1$ and $\mathrm{C}-2^{\prime}$ linkage patterns. Thus, the structure of 4 was finally established as 2,7'-dihydroxy-4,7,5' -trimethoxy-9' $10^{\prime}$-dihydro-1,2'-biphenanthreneether, and named as cremaphenanthrene D.

Table 3. ${ }^{1} \mathrm{H}-\mathrm{NMR}$ Data of compounds 4-7.

\begin{tabular}{|c|c|c|c|c|}
\hline Proton & 4 & 5 & 6 & 7 \\
\hline 3 & $6.94 \mathrm{~s}$ & $7.04 \mathrm{~s}$ & $6.94 \mathrm{~s}$ & $6.94 \mathrm{~s}$ \\
\hline 5 & $9.45 \mathrm{~d}(9.5)$ & $9.51 \mathrm{~d}(9.5)$ & $9.41 \mathrm{~d}(9.5)$ & $9.41 \mathrm{~d}(9.5)$ \\
\hline 6 & $7.20 \mathrm{dd}(9.5,3.0)$ & $7.24 \mathrm{dd}(9.5,3.0)$ & $7.11 \mathrm{dd}(9.5,3.0)$ & $7.11 \mathrm{dd}(9.5,3.0)$ \\
\hline 8 & $7.26 \mathrm{~d}(3.0)$ & $7.37 \mathrm{~d}(3.0)$ & $7.14 \mathrm{~d}(3.0)$ & $7.13 \mathrm{~d}(3.0)$ \\
\hline 9 & $7.59 \mathrm{~d}(9.5)$ & $7.70 \mathrm{~d}(9.5)$ & $7.52 \mathrm{~d}(9.5)$ & $7.50 \mathrm{~d}(9.5)$ \\
\hline 10 & $7.70 \mathrm{~d}(9.5)$ & $7.74 \mathrm{~d}(9.5)$ & $7.67 \mathrm{~d}(9.5)$ & $7.66 \mathrm{~d}(9.5)$ \\
\hline $1^{\prime}$ & $6.67 \mathrm{~d}(3.0)$ & $6.20 \mathrm{~d}(3.0)$ & $6.24 \mathrm{~d}(3.0)$ & $6.66 \mathrm{~d}(3.0)$ \\
\hline $3^{\prime}$ & $6.69 \mathrm{dd}(9.5,3.0)$ & $6.65 \mathrm{~d}(3.0)$ & $6.58 \mathrm{~d}(3.0)$ & $6.67 \mathrm{dd}(9.5,3.0)$ \\
\hline $4^{\prime}$ & $8.05 \mathrm{~d}(9.5)$ & & & $8.02 \mathrm{~d}(9.5)$ \\
\hline $5^{\prime}$ & & 8.07 d (9.0) & 8.02 d (9.5) & \\
\hline $6^{\prime}$ & $6.38 \mathrm{~d}(3.0)$ & $6.69 \mathrm{dd}(9.0,3.0)$ & $6.61 \mathrm{dd}(9.5,3.0)$ & $6.39 \mathrm{~d}(3.0)$ \\
\hline $8^{\prime}$ & $6.29 \mathrm{~d}(3.0)$ & $6.68 \mathrm{~d}(3.0)$ & $6.60 \mathrm{~d}(3.0)$ & $6.29 \mathrm{~d}(3.0)$ \\
\hline $9^{\prime}$ & $2.61-2.63 \mathrm{~m}^{\mathrm{a}}$ & $2.59-2.60 \mathrm{~m}$ & $2.59-2.63 \mathrm{~m}$ & $2.61-2.63 \mathrm{~m}^{\mathrm{a}}$ \\
\hline $10^{\prime}$ & $2.61-2.63 \mathrm{~m}^{\mathrm{a}}$ & $2.53-2.56 \mathrm{~m}$ & $2.54-2.58 \mathrm{~m}$ & $2.61-2.63 \mathrm{~m}^{\mathrm{a}}$ \\
\hline $4-\mathrm{OCH}_{3}$ & $4.12 \mathrm{~s}$ & $4.16 \mathrm{~s}$ & $4.12 \mathrm{~s}$ & $4.12 \mathrm{~s}$ \\
\hline $7-\mathrm{OCH}_{3}$ & $3.91 \mathrm{~s}$ & $3.94 \mathrm{~s}$ & & \\
\hline $4^{\prime}-\mathrm{OCH}_{3}$ & & $3.81 \mathrm{~s}$ & $3.75 \mathrm{~s}$ & \\
\hline $5^{\prime}-\mathrm{OCH}_{3}$ & $3.80 \mathrm{~s}$ & & & $3.80 \mathrm{~s}$ \\
\hline
\end{tabular}

${ }^{1} \mathrm{H}-\mathrm{NMR}$ data were measured at $500 \mathrm{MHZ}$ in $\mathrm{CD}_{3} \mathrm{OD}$ for $4,6-7$, in acetone- $d_{6}$ for $5, \delta$ in ppm, $J$ in $\mathrm{Hz}$;

a overlapped; the number in brackets represented coupling constants. 
Table 4. ${ }^{13}$ C-NMR Data of compounds 4-7.

\begin{tabular}{|c|c|c|c|c|}
\hline Carbon & 4 & 5 & 6 & 7 \\
\hline 1 & 130.9 & 130.0 & 130.8 & 131.0 \\
\hline 2 & 148.6 & 148.0 & 148.0 & 148.0 \\
\hline 3 & 101.3 & 101.1 & 101.1 & 101.2 \\
\hline 4 & 157.6 & 157.4 & 157.7 & 157.7 \\
\hline 5 & 130.3 & 130.2 & 130.6 & 130.6 \\
\hline 6 & 117.5 & 117.7 & 117.9 & 117.8 \\
\hline 7 & 158.3 & 158.1 & 155.7 & 155.9 \\
\hline 8 & 109.6 & 109.6 & 112.6 & 112.5 \\
\hline 9 & 129.1 & 129.3 & 129.2 & 129.1 \\
\hline 10 & 121.5 & 121.3 & 121.4 & 121.5 \\
\hline $4 a$ & 116.4 & 116.1 & 116.8 & 116.8 \\
\hline $4 b$ & 126.2 & 125.8 & 125.5 & 125.5 \\
\hline $8 a$ & 134.4 & 134.1 & 134.4 & 134.8 \\
\hline $10 a$ & 129.4 & 129.0 & 129.3 & 129.3 \\
\hline $1^{\prime}$ & 114.7 & 107.3 & 107.9 & 114.9 \\
\hline $2^{\prime}$ & 158.3 & 159.1 & 159.6 & 158.5 \\
\hline $3^{\prime}$ & 113.5 & 99.6 & 99.6 & 113.6 \\
\hline $4^{\prime}$ & 129.9 & 158.8 & 159.3 & 130.1 \\
\hline $5^{\prime}$ & 159.3 & 130.2 & 130.4 & 159.3 \\
\hline $6^{\prime}$ & 99.3 & 113.6 & 113.8 & 99.4 \\
\hline $7^{\prime}$ & 158.0 & 156.5 & 156.6 & 158.0 \\
\hline $8^{\prime}$ & 108.4 & 115.1 & 115.2 & 108.5 \\
\hline $9^{\prime}$ & $31.6^{\mathrm{a}}$ & $31.4^{b}$ & $30.8^{c}$ & $30.8^{d}$ \\
\hline $10^{\prime}$ & $31.2^{\mathrm{a}}$ & $30.6^{b}$ & $31.2^{\mathrm{c}}$ & $31.4^{\mathrm{d}}$ \\
\hline $4 a^{\prime}$ & 128.2 & 118.5 & 118.9 & 128.3 \\
\hline $4 b^{\prime}$ & 116.3 & 125.3 & 125.9 & 116.6 \\
\hline $8 a^{\prime}$ & 142.0 & 140.3 & 140.9 & 142.2 \\
\hline $10 a^{\prime}$ & 140.5 & 141.3 & 142.0 & 140.7 \\
\hline $4-\mathrm{OCH}_{3}$ & 56.3 & 56.4 & 56.4 & 56.4 \\
\hline $7-\mathrm{OCH}_{3}$ & 55.8 & 55.7 & & \\
\hline $4^{\prime}-\mathrm{OCH}_{3}$ & & 56.0 & 56.1 & \\
\hline $5^{\prime}-\mathrm{OCH}_{3}$ & 56.0 & & & 56.0 \\
\hline
\end{tabular}

${ }^{13} \mathrm{C}-\mathrm{NMR}$ data were measured at $125 \mathrm{MHZ}$ in $\mathrm{CD}_{3} \mathrm{OD}$ for $4,6-7$, in acetone- $d_{6}$ for $5, \delta$ in ppm; ${ }^{\text {a-d }}$ the signals under the same superscript may be interchanged.

Compound 5 (Tables 3 and 4, Figure 2) was obtained as a brown amorphous powder. The molecular formula was deduced as $\mathrm{C}_{31} \mathrm{H}_{26} \mathrm{O}_{6}$ according to the appearance of a negative $[\mathrm{M}-\mathrm{H}]^{-}$ion at $m / z 493.1665$ in the HR-ESI-MS of 5 . Compounds 5 and 4 have identical molecular formula and similar IR, UV, and 1D-NMR spectra, as well as the same connection site between phenanthrene moiety and $2^{\prime}, 7^{\prime}$-dihydroxy-4'-methoxy-9,10-dihydrophenanthrene. This was confirmed by the vital NOESY correlations from $\mathrm{H}-10\left(\delta_{\mathrm{H}} 7.74\right)$ to $\mathrm{H}-1^{\prime}\left(\delta_{\mathrm{H}} 6.20\right)$. Thus, we elucidated the structure of 5 as 2,7'-dihydroxy-4,7,4'-trimethoxy-9' $17^{\prime}$-dihydro-1,2'-biphenanthreneether, and named as cremaphenanthrene $\mathrm{E}$.

Compounds 6 and 7 (Tables 3 and 4, Figure 2) were obtained as brown amorphous powders. The molecular formula was deduced as $\mathrm{C}_{30} \mathrm{H}_{24} \mathrm{O}_{6}$ according to their HR-ESI-MS. Their IR, UV, and 1D-NMR spectra were similar with those of 4 and 5, but their molecular weights were fourteen mass units less than those of 4 and 5 . All of the above information indicated the character of biphenanthreneether of 6 and 7. Compared with 5, 6 had a hydroxyl located at C-7 instead of a methoxyl in the same position of 5, which was confirmed by the HMBC correlations from H-5 to C-7. Thus, the structure of 6 was elucidated as 2,7,7'-trihydroxy4,4'-dimethoxy-9', $10^{\prime}$-dihydro-1,2'-biphenanthreneether. It was a known compound with the name blestrin C [12]. In comparation with 4,7 also possessed a hydroxyl located at C-7 instead of a methoxyl in the corresponding position of 4 , the HMBC correlations from H-5 to C-7 
further confirmed the deduction. Therefore, the structure of 7 was defined as 2,7,7'-trihydroxy4,5'-dimethoxy-9', $10^{\prime}$-dihydro-1,2'-biphenanthreneether, which was a known compound having the name blestrin $\mathrm{D}$ [12]. The assignments of ${ }^{1} \mathrm{H}-,{ }^{13} \mathrm{C}-\mathrm{NMR}$ data of blestrin $\mathrm{C}(6)$ and $\mathrm{D}(7)$ in the literature were partly different with ours [12]. In this paper, we assigned 1D NMR data of the two compounds based on the comprehensive analyses of ${ }^{1} \mathrm{H}-\mathrm{NMR},{ }^{13} \mathrm{C}-\mathrm{NMR}, \mathrm{HSQC}, \mathrm{HMBC}$, and NOESY spectra.

Other four known biphenanthrenes were identified as 4,7, $4^{\prime}$-trimethoxy- $9^{\prime}, 10^{\prime}$-dihydro (1,1'-biphenanthrene)-2,2', $7^{\prime}$-triol (8) [11], phochinenin B (9) [6], 2,7, $2^{\prime}$-trihydroxy-4, $4^{\prime}, 7^{\prime}$-trimethoxy1,1'-biphenanthrene (10) [2], and 2,2'-dihydroxy-4,4',7,7'-tetramethoxy-1,1'-biphenanthrene(11) [2] by comparison spectroscopic data with those in literatures.

\subsection{Cytotoxicity Assay}

The cytotoxicities of 1-11 were evaluated by the MTT method [2], using paclitaxel as a positive control. Their cytotoxicities against human colon (HCT-116), cervix (Hela), and breast (MDA-MB-231) cancer cell lines were determined. The results (Table 5) indicated that 1-11 showed moderate or weak cytotoxicities to the tested cancer cell lines. Among them, compounds 10 and $\mathbf{1 1}$ showed moderate cytotoxicities to all the above cancer cell lines with $\mathrm{IC}_{50}$ values range of $(12.13 \pm 0.38)-(17.43 \pm 3.07) \mu \mathrm{mol} / \mathrm{L}$. They are all hexasubstituted phenanthrene-phenanthrene dimer with hydroxyl and methoxyl located at C-2, C-2', C-4, C-4' ${ }^{\prime}, \mathrm{C}-7$, and C-7'. Compound 8 was a phenanthrene-9,10-dihydrophenanthrene dimer with the identical substitution pattern to 10 . However, 8 only had weak cytotoxicities against the tested three cancer cell lines. Compounds 3 and 8 had the same phenanthrene and 9,10-dihydrophenanthrene moieties with the different linkage positions (1-1' or 3-1' connections, respectively), while the cytotoxicities of 3 were better than those of $\mathbf{8}$, which indicated that the linkage position of phenanthrene and 9,10-dihydrophenanthrene moieties affected the activity. All of the above results suggested that the cytotoxicities of biphenanthrenes might be associated with the following factors: the number of substituted hydroxyl and methoxyl, the hydroxyl and methoxyl location, the linkage position of two phenanthrene moieties, and the type of moiety (phenanthrene or 9,10-dihydrophenanthrene).

Table 5. $\mathrm{IC}_{50}$ values $(\mu \mathrm{mol} / \mathrm{L})$ of compounds $\mathbf{1 - 1 1}$ against tumor cell lines.

\begin{tabular}{cccc}
\hline \multirow{2}{*}{ Compounds } & \multicolumn{3}{c}{ Cell Lines } \\
\cline { 2 - 4 } & HCT-116 & Hela & MDA-MB-231 \\
\hline $\mathbf{1}$ & $92.24 \pm 8.41$ & $38.08 \pm 5.16$ & $>100$ \\
$\mathbf{2}$ & $63.62 \pm 3.40$ & $44.15 \pm 4.31$ & $65.55 \pm 4.07$ \\
$\mathbf{3}$ & $26.53 \pm 6.14$ & $19.94 \pm 2.07$ & $15.80 \pm 3.31$ \\
$\mathbf{4}$ & $33.03 \pm 4.50$ & $24.71 \pm 3.21$ & $56.14 \pm 4.33$ \\
$\mathbf{5}$ & $>100$ & $39.17 \pm 6.59$ & $>100$ \\
$\mathbf{6}$ & $41.15 \pm 6.31$ & $>100$ & $>100$ \\
$\mathbf{7}$ & $86.49 \pm 9.59$ & $>100$ & $>100$ \\
$\mathbf{8}$ & $32.33 \pm 4.77$ & $64.81 \pm 5.72$ & $45.46 \pm 2.91$ \\
$\mathbf{9}$ & $15.01 \pm 1.90$ & $>100$ & $11.09 \pm 2.89$ \\
$\mathbf{1 0}$ & $14.05 \pm 2.25$ & $17.43 \pm 3.07$ & $13.86 \pm 3.33$ \\
$\mathbf{1 1}$ & $14.39 \pm 0.26$ & $13.23 \pm 1.95$ & $12.13 \pm 0.38$ \\
paclitaxel & $1.05 \pm 0.23$ & $0.09 \pm 0.01$ & $0.016 \pm 0.003$ \\
\hline
\end{tabular}

\section{Experimental Section}

\subsection{General Experimental Procedures}

UV spectra were run on a Shimadzu UV-2450 spectrometer (Shimadzu, Tokyo, Japan). IR spectra were recorded on a Thermo Nicolet NEXUS-470 FTIR spectrometer (Thermo-Niolet, Madison, WI, USA). HR-ESI-MS were determined by a Bruker APEX IV FT-MS (7.0 T) (Bruker, Bremen, Germany) and a Waters Xevo G2 Q-TOF/YCA mass spectrometers (Waters, Milford, MA, USA). NMR spectra 
were recorded on a Varian Inova-500 (Varian, Palo Alto, CA, USA) and a Bruker Avance-600 FT NMR spectrometers $\left(25{ }^{\circ} \mathrm{C}\right)$ (Bruker, Karlsruhe, Germany). Semi-preparative HPLC were run on a Dionex Ultimate 3000 instrument (Dionex, Sunnyvale, CA, USA) equipped with 170U UV Detector (254 nm) and an ODS column (Waters Co., Milford, MA, USA; $250 \mathrm{~mm} \times 10 \mathrm{~mm}, 5 \mu \mathrm{m}$ ). Column chromatography (CC) was performed using silica gel (200-300 mesh, Qingdao Marine Chemistry Ltd., Qingdao, China), Sephadex LH-20 (Amersham Biosciences, Uppsala, Sweden) and ODS C $_{18}(40-63 \mu \mathrm{m}$, Merck, Darmstadt, Germany). TLC was carried out on glass precoated silica gel (GF254) plates (Qingdao Marine Chemistry Ltd., Qingdao, China). Spots were visualized under UV light and detected by spraying with $10 \% \mathrm{H}_{2} \mathrm{SO}_{4}$ in $\mathrm{EtOH}$ followed by heating. All purified compounds submitted for bioassay were at least 95\% pure, as judged by HPLC analyses.

\subsection{Plant Material}

The tubers of $C$. appendiculata were collected in Yunnan province in June 2011. The plant materials were identified by one of the authors (Prof. P.F. Tu), and a voucher specimen (No. DJL20110628) was deposited at the Herbarium of Peking University Modern Research Center for Traditional Chinese Medicine.

\subsection{Extraction and Isolation}

The powdered, dry tubers of C. appendiculata $(30 \mathrm{~kg})$ were extracted with $95 \% \mathrm{EtOH}(100 \mathrm{~L})$ three times, each for two hours. After filtration and evaporation, a dark brown residue was obtained. The residue was suspended in distilled water and partitioned successively with PE $(3 \times 10 \mathrm{~L}), \mathrm{EtOAc}$ $(3 \times 10 \mathrm{~L})$, and $n-\mathrm{BuOH}(3 \times 15 \mathrm{~L})$. Part of the PE fraction $(33.3 \mathrm{~g})$ was separated by silica gel column chromatography $(C C, 6 \times 60 \mathrm{~cm})$ eluted with a gradient of PE-EtOAc (50:1-0:100) to give nine fractions (Fraction A-I) based on TLC analysis. Fraction H (1.4 g) was chromatographed on a silica gel column $(3 \times 30 \mathrm{~cm})$ using a gradient of PE-acetone (4:1-0:100) to get nine fractions $(\mathrm{H} 1-\mathrm{H} 9)$. Fraction $\mathrm{H} 8$ $(58.0 \mathrm{mg})$ was then subjected to $\mathrm{CC}(2.5 \times 30 \mathrm{~cm})$ on a silica gel employing $\mathrm{CHCl}_{3}$-acetone $(10: 1)$ to yield compound $11(6.0 \mathrm{mg})$. Fraction I $(0.9 \mathrm{~g})$ was separated by silica gel CC $(2.5 \times 30 \mathrm{~cm})$ eluted with a PE-acetone gradient (4:1-0:100) to give six fractions (Fraction I1-I6). Fraction I6 (140.0 mg) was then subjected to $\mathrm{CC}(3.0 \times 80 \mathrm{~cm})$ on Sephadex $\mathrm{LH}-20$ using $\mathrm{CHCl}_{3}: \mathrm{MeOH}(2: 1)$ as eluent to obtain compound $10(10.2 \mathrm{mg})$. The EtOAc fraction was isolated by silica gel CC $(8.0 \times 60 \mathrm{~cm})$ eluted with a gradient of $\mathrm{CHCl}_{3}: \mathrm{MeOH}(50: 1-0: 100)$ to give nine fractions (Fraction A-I) using TLC analysis. Thirteen fractions (A1-A13) were obtained from Fraction A (21.6 g) chromatographed on a silica gel column $(5.0 \times 50 \mathrm{~cm})$ using a gradient of PE:acetone (5:2-0:100) as eluent. Fraction A9 $(1.8 \mathrm{~g})$ was subjected to CC $(3.0 \times 80 \mathrm{~cm})$ on Sephadex LH-20 employing $\mathrm{CHCl}_{3}: \mathrm{MeOH}(2: 1)$ to yield 10 fractions (A9-1 to A9-10). Fraction A9-9 (58.5 mg) was separated by semi-preparative HPLC, using acetonitrile (ACN): $\mathrm{H}_{2} \mathrm{O}(3: 2,2.0 \mathrm{~mL} / \mathrm{min})$, then $\mathrm{MeOH}: \mathrm{H}_{2} \mathrm{O}(4: 1,2.0 \mathrm{~mL} / \mathrm{min})$ as mobile phase to yield compound $4\left(2.6 \mathrm{mg}, \mathrm{t}_{\mathrm{R}}=31.5 \mathrm{~min}\right)$ and $5\left(2.8 \mathrm{mg}, \mathrm{t}_{\mathrm{R}}=33 \mathrm{~min}\right)$. Fraction A11 (2.1 g) was separated into nine fractions (A11-1 to A11-9) by a Sephadex LH-20 CC $(3.0 \times 80 \mathrm{~cm})$ and washed with $\mathrm{CHCl}_{3}: \mathrm{MeOH}(1: 2)$. Fraction A11-5 (135.8 mg) was applied to a silica gel CC $(2.5 \times 30 \mathrm{~cm})$ using $\mathrm{PE}: \mathrm{CHCl}_{3}: \mathrm{MeOH}(5: 5: 1)$, then further purified by semi-preparative HPLC, eluted with $\mathrm{ACN}: \mathrm{H}_{2} \mathrm{O}(11: 9,2.0 \mathrm{~mL} / \mathrm{min})$ as the mobile phase, to yield compounds $8\left(1.8 \mathrm{mg}, \mathrm{t}_{\mathrm{R}}=34.9 \mathrm{~min}\right)$ and $3\left(1.6 \mathrm{mg}, \mathrm{t}_{\mathrm{R}}=28.9 \mathrm{~min}\right)$. Fraction A12 $(2.7 \mathrm{~g})$ was subjected by a silica gel CC $(3.0 \times 30 \mathrm{~cm})$ and eluted with a gradient of $\mathrm{CHCl}_{3}$ :EtOAc (3:1-0:100) to afford 10 fractions (Fraction A12-1 to A12-10). Fraction A12-5 (282.3 mg) was separated into 10 fractions (A12-5-1 to A12-5-10) by a Sephadex LH-20 CC $(3.0 \times 80 \mathrm{~cm})$ using MeOH. Fraction A12-5-6 $(48.3 \mathrm{mg})$ was purified by semi-preparative HPLC, using ACN-H $\mathrm{A}_{2} \mathrm{O}(11: 9$, then $21: 29,2.0 \mathrm{~mL} / \mathrm{min})$ as the mobile phase, to yield compounds 6 $\left(3.2 \mathrm{mg}, \mathrm{t}_{\mathrm{R}}=55.5 \mathrm{~min}\right)$ and $7\left(2.6 \mathrm{mg}, \mathrm{t}_{\mathrm{R}}=61.0 \mathrm{~min}\right)$. Fraction A12-6 $(372.6 \mathrm{mg})$ was separated on a RP-C18 silica gel CC $(3.0 \times 30 \mathrm{~cm})$ eluted with a gradient of $\mathrm{MeOH}-\mathrm{H}_{2} \mathrm{O}(2: 1-100: 0)$ to give 10 fractions (A12-6-1 to A12-6-10). Compound 2 (3.2 $\mathrm{mg}, \mathrm{t}_{\mathrm{R}}=35.0 \mathrm{~min}$ ) was finally obtained from Fraction A12-6-3 (45.2 mg) through semi-preparative $\operatorname{HPLC}\left(\mathrm{ACN}: \mathrm{H}_{2} \mathrm{O}(11: 9,2.0 \mathrm{~mL} / \mathrm{min})\right)$. Original extract Fraction $\mathrm{B}$ 
of EtOAc fraction $(12.91 \mathrm{~g})$ was separated on a silica gel CC $(5.0 \times 50 \mathrm{~cm})$ using PE:acetone:MeOH (5:5:1.2-0:0:100) to obtain seven fractions (B1-B7). Fraction B2 (3.85 g) was then further fractionated on a Sephadex LH-20 CC $(3.0 \times 80 \mathrm{~cm})$ eluted with $\mathrm{CHCl}_{3}: \mathrm{MeOH}(1: 1)$ to give eight fractions (B2-1 to B2-8). Fraction B2-4 (540.0 mg) was separated on a silica gel CC $(3.0 \times 30 \mathrm{~cm})$ employing $\mathrm{CHCl}_{3}$-acetone (5:1) to get three fractions (B2-4-1 to B2-4-3), Fraction B2-4-1 (135.2 mg) was purified by a RP-C18 CC $(2.5 \times 30 \mathrm{~cm})$ eluted with a $\mathrm{MeOH}: \mathrm{H}_{2} \mathrm{O}$ gradient $(2: 1-100: 0)$, then by a Sephadex LH-20 CC $(3.0 \times 80 \mathrm{~cm})$ and washed with $\mathrm{MeOH}$ to yield compound $9(28.2 \mathrm{mg})$. Fraction D of EtOAc fraction $(3.5 \mathrm{~g})$ was separated into six fractions (D1-D6) by a silica gel CC $(3.0 \times 30 \mathrm{~cm})$ eluted with a gradient of PE:EtOAc (1:1-0:100). Fraction D5 (260.0 mg) was further applied to a Sephadex LH-20 $\mathrm{CC}(3.0 \times 80 \mathrm{~cm})$ using a $\mathrm{CHCl}_{3}: \mathrm{MeOH}$ gradient (1:2-0:100) to afford four fractions (D5-1 to D5-4). Fraction D5-4 $(20.0 \mathrm{mg})$ was purified by a RP-C18 silica gel CC $(2.0 \times 20 \mathrm{~cm})$ washed with a gradient of $\mathrm{MeOH}: \mathrm{H}_{2} \mathrm{O}$ (3:1-100:0) to yield two fractions (D5-4-1 to D5-4-2), compound $\mathbf{1}$ (5.2 mg, $\mathrm{t}_{\mathrm{R}}=35.0 \mathrm{~min}$ ) was then purified from Fraction D5-4-2 $(11.0 \mathrm{mg})$ by semi-preparative HPLC, using $\mathrm{MeOH}-\mathrm{H}_{2} \mathrm{O}$ $(3: 2,2.0 \mathrm{~mL} / \mathrm{min})$ as the mobile phase.

\subsection{Spectroscopic Data}

Cremaphenanthrene $A(\mathbf{1})$ : brown amorphous powder. UV $\lambda_{\max }(\mathrm{MeOH}) \mathrm{nm}(\log \varepsilon): 203$ (0.77), 264 (1.81), 308 (0.29). IR (KBr) $\gamma_{\max }\left(\mathrm{cm}^{-1}\right)$ : 3239, 1612, 1588 and 1206. ${ }^{1} \mathrm{H}$ - and ${ }^{13} \mathrm{C}-\mathrm{NMR}$ data: Tables 1 and 2. Positive ion HR-ESI-MS $m / z$ 1011.2639 [2M + Na] (calcd for $\mathrm{C}_{30} \mathrm{H}_{22} \mathrm{O}_{7}, 1011.2623$ ).

Cremaphenanthrene $B(2)$ : brown amorphous powder. UV $\lambda_{\max }(\mathrm{MeOH}) \mathrm{nm}(\log \varepsilon): 212(0.50), 264$ (1.12), 310 (0.22). IR (KBr) $v_{\max }\left(\mathrm{cm}^{-1}\right): 3345,1615,1463,1370$ and 1023. ${ }^{1} \mathrm{H}-$ and ${ }^{13} \mathrm{C}-\mathrm{NMR}$ data: Tables 1 and 2. Negative ion HR-ESI-MS $m / z$ 507.1455 [M - H] ${ }^{-}$(calcd for $\mathrm{C}_{31} \mathrm{H}_{24} \mathrm{O}_{7}$, 507.1449).

Cremaphenanthrene $C$ (3): brown amorphous powder. UV $\lambda_{\max }(\mathrm{MeOH}) \mathrm{nm}(\log \varepsilon): 211$ (1.19), 263 (1.33). IR (KBr) $v_{\max }\left(\mathrm{cm}^{-1}\right): 3402,2931,1611,1586,1460$ and 1275. ${ }^{1} \mathrm{H}-$ and ${ }^{13} \mathrm{C}-\mathrm{NMR}$ data: Tables 1 and 2. Positive ion HR-ESI-MS $m / z 495.1795[\mathrm{M}+\mathrm{H}]^{+}$(calcd for $\mathrm{C}_{31} \mathrm{H}_{26} \mathrm{O}_{6}, 495.1808$ ).

Cremaphenanthrene $D(4)$ : brown amorphous powder. UV $\lambda_{\max }(\mathrm{MeOH}) \mathrm{nm}(\log \varepsilon)$ : $211(0.81), 263(1.02)$. IR (KBr) $v_{\max }\left(\mathrm{cm}^{-1}\right): 3416,2933,1611,1357,1215$ and $1084 .{ }^{1} \mathrm{H}$ - NMR and ${ }^{13} \mathrm{C}-\mathrm{NMR}$ data: Tables 3 and 4. Negative ion HR-ESI-MS $m / z 493.1637[\mathrm{M}-\mathrm{H}]^{-}$(calcd for $\mathrm{C}_{31} \mathrm{H}_{26} \mathrm{O}_{6}, 493.1657$ ).

Cremaphenanthrene $E$ (5): brown amorphous powder. UV $\lambda_{\max }(\mathrm{MeOH}) \mathrm{nm}(\log \varepsilon)$ : $211(0.63), 263(0.98)$. IR (KBr) $v_{\max }\left(\mathrm{cm}^{-1}\right): 3411,2934,1608,1531,1127$ and 1009. ${ }^{1} \mathrm{H}-$ and ${ }^{13} \mathrm{C}-\mathrm{NMR}$ data: Tables 3 and 4. Negative ion HR-ESI-MS $m / z 493.1665[\mathrm{M}-\mathrm{H}]^{-}$(calcd for $\mathrm{C}_{31} \mathrm{H}_{26} \mathrm{O}_{6}, 493.1657$ ).

\subsection{Cytotoxic Bioassay}

MTT assays were performed to evaluate cytotoxic activities of all the compounds as previously reported [2]. Paclitaxel was served as a positive control. Data are presented as mean for three independent experiments. Each concentration of compounds was tested in three parallel wells. $\mathrm{IC}_{50}$ values were calculated using Microsoft Excel software.

\section{Conclusions}

Phytochemical investigations have led to the isolation of five new biphenanthrenes (1-5), together with six known ones (6-11), four of which (6-9) were reported from the genus Cremastra for the first time.

The tubers of $C$. appendiculata are a famous traditional Chinese medicine with a long history for treating cancers. In this study, eleven biphenanthrenes have been obtained from the tubers of C. appendiculata and proved to have moderate or weak cytotoxicities to several cancer cell lines, which could account for the traditional usage of $C$. appendiculata as anti-cancer agent. Therefore, these biphenanthrenes might serve as chemical markers for quality control of this herb. 
Supplementary Materials: Supplementary materials can be accessed at: http://www.mdpi.com/1420-3049/21/ 8/1089/s1.

Acknowledgments: This research work was supported by National Key Technology R\&D Program “New Drug Innovation" of China (No. 2012ZX09301002-002-002 and 2012ZX09304-005).

Author Contributions: L.L. fractionated the extract, isolated the compounds, elucidated the structures, and wrote the paper. K.-W.Z. performed the bioassays. J.L. analyzed the data. J.L., Y.J. and P.-F.T. reviewed the manuscript.

Conflicts of Interest: The authors declare no conflict of interest.

\section{References}

1. Kovács, A.; Vasas, A.; Hohmann, J. Natural phenanthrenes and their biological activity. Phytochemistry 2008, 69, 1084-1110. [CrossRef] [PubMed]

2. Xue, Z.; Li, S.; Wang, S.J.; Wang, Y.H.; Yang, Y.C.; Shi, J.G.; He, L. Mono-, Bi-, and triphenanthrenes from the tubers of Cremastra appendiculata. J. Nat. Prod. 2006, 69, 907-913. [CrossRef] [PubMed]

3. Wang, Y.; Guan, S.H.; Meng, Y.H.; Zhang, Y.B.; Cheng, C.R.; Shi, Y.Y.; Feng, R.H.; Zeng, F.; Wu, Z.Y.; Zhang, J.X.; et al. Phenanthrenes, 9,10-dihydrophenanthrenes, bibenzyls, with their derivatives, and malate or tartrate benzyl ester glucosides from tubers of Cremastra appendiculata. Phytochemistry 2013, 94, 268-276. [CrossRef] [PubMed]

4. Yang, M.H.; Cai, L.; Tai, Z.G.; Zeng, X.H.; Ding, Z.T. Four new phenanthrenes from Monomeria barbata Lindl. Fitoterapia 2010, 81, 992-997. [CrossRef] [PubMed]

5. Xu, J.J.; Yu, H.; Qing, C.; Zhang, Y.L.; Liu, Y.; Chen, Y.G. Two new biphenanthrenes with cytotoxic activity from Bulbophyllum odoratissimum. Fitoterapia 2009, 80, 381-384. [CrossRef] [PubMed]

6. Yao, S.; Tang, C.P.; Li, X.Q.; Ye, Y. Phochinenins A-F, dimeric 9,10-dihydrophenanthrene derivatives, from Pholidota chinensis. Helv. Chim. Acta 2008, 91, 2122-2129. [CrossRef]

7. Apel, C.; Dumontet, V.; Lozach, O.; Meijer, L.; Guéritte, F.; Litaudon, M. Phenanthrene derivatives from Appendicula reflexa as new CDK1/cyclin B inhibitors. Phytochem. Lett. 2012, 5, 814-818. [CrossRef]

8. Majumder, P.L.; Bandyopadhyay, S.; Pal, S. Rigidanthrin, a new dimeric phenanthrene derivative of the orchid Bulbophyllum rigidum. J. Indian Chem. Soc. 2008, 85, 1116-1123.

9. Majumder, P.L.; Mukhoti, N.; Chattopadhyay, S. Agrostophyllanthrol and isoagrostophyllanthrol, two novel diastereomeric phenanthropyran derivatives from the orchid Agrostophyllum khasiyanum. J. Indian Chem. Soc. 2008, 85, 1315-1325. [CrossRef]

10. Gutierrez, R.M.P.; Gonzalez, A.M.N.; Baez, E.G.; Diaz, S.L. Studies on the constituents of bulbs of the orchid Prosthechea michuacana and antioxidant activity. Chem. Nat. Compd. 2010, 46, 554-561. [CrossRef]

11. Qian, C.D.; Jiang, F.S.; Yu, H.S.; Shen, Y.; Fu, Y.H.; Cheng, D.Q.; Gan, L.S.; Ding, Z.S. Antibacterial biphenanthrenes from the Fibrous Roots of Bletilla Striata. J. Nat. Prod. 2015, 78, 939-943. [CrossRef] [PubMed]

12. Masae, Y.; Li, B.; Tomoko, K.; Keiko, I.; Shuzo, T.; Yuriko, Y.; Kenichi, T. Bisphenanthreneethers from Bletilla striata. Phytochemistry 1992, 31, 3985-3987.

13. Liu, L.; Ye, J.; Li, P.; Tu, P.F. Chemical constituents of tubers of Cremastra appendiculata. Chin. J. Chin. Mater. Med. 2014, 39, 250-253.

14. Editorial Committee of the Administration Bureau of Traditional Chinese Medicine. Chinese Materia Medica (Zhong Hua Ben Cao); Shanghai Science and Technology Press: Shanghai, China, 1999; Volume 6, p. 7828

15. Liu, L.; Li, J.; Zeng, K.W.; Li, P.; Tu, P.F. Three new phenanthrenes from Cremastra appendiculata (D. Don) Makino. Chin. Chem. Lett. 2013, 24, 737-739. [CrossRef]

16. Liu, L.; Li, J.; Zeng, K.W.; Li, P.; Tu, P.F. Five new benzylphenanthrenes from Cremastra appendiculata. Fitoterapia 2015, 103, 27-32. [CrossRef] [PubMed]

Sample Availability: Not available.

(C) 2016 by the authors; licensee MDPI, Basel, Switzerland. This article is an open access article distributed under the terms and conditions of the Creative Commons Attribution (CC-BY) license (http://creativecommons.org/licenses/by/4.0/). 